\title{
PEMBUATAN KREASI PRODUK CAMILAN DODOL ASAM JAWA MENGGUNAKAN PENGUJIAN ORGANOLEPTIK
}

\author{
Juliana $^{1}$, Marselina Putri Kanggeyan ${ }^{2}$, Sherly ${ }^{3}$ \\ Pengelolaan Perhotelan, Fakultas Pariwisata, Universitas Pelita Harapan \\ MH Thamrin Boulevard 1100 Kelapa Dua Karawaci Tangerang Banten \\ juliana.stpph@uph.edu ${ }^{1}$, mpkanggeyan@gmail.com² sujantosherly@gmail.com $^{3}$
}

\begin{abstract}
ABSTRAK
Asam jawa merupakan buah yang asam rasanya, dan tumbuh dengan sendirinya di pinggir jalan dan di pekarangan rumah. Asam jawa sendiri sudah dikenal masyarakat dan dijadikan minuman herbal, dan bumbu pada masakan. Dodol tradisonal umumnya terbuat dari campuran tepung ketan, gula merah, gula pasir, dan santan. Dodol juga dapat dibuat menggunakan sayur dan buah, beberapa produk dodol dari buah yaitu, dodol nanas, dodol, nangka, dan lain sebagainya. Pengembangan daging asam jawa sebagai bahan baku dodol akan menciptakan cita rasa berbeda pada dodol, yaitu perpaduan rasa asam dan manis, dengan tekstur kenyal khas dodol. Dalam penelitian ini peneliti menggunakan metode eksperimen untuk menghasilkan dodol asam jawa yang memiliki warna, tekstur, rasa, aroma, dan penampilan yang baik. Untuk mengetahui respons panelis mengenai dodol asam jawa, peneliti melakukan uji organoleptik melalui uji mutu hedonik dan uji hedonik yang melibatkan 30 panelis terlatih. Dengan mengembangkan inovasi tersebut diharapkan dapat mengenalkan bahwa daging asam jawa tidak hanya dapat dijadikan bumbu dalam masakan dan minuman herbal, melainkan dapat dinikmati dalam bentuk camilan dodol. Hasil penelitian didapatkan bahwa penggunaan daging asam jawa memiliki kelayakan sebagai bahan baku pembuatan dodol. Penelitian dan pengembangan terhadap dodol menggunakan daging asam jawa menghasilkan camilan yang layak untuk dikonsumsi karena menghasilkan dodol yang memiliki rasa yang baik, tekstur yang kenyal, aroma yang sedap, warna yang alami, serta penampilan menarik.
\end{abstract}

Kata Kunci: Asam Jawa, Dodol, Camilan,uji organoleptik

\begin{abstract}
Tamarind is a fruit that tastes sour, and grows by itself on the roadside and in the yard of the house. Tamarind itself is already known to the public and used as herbal drinks, and spices in cooking. Traditional dodol is generally made from a mixture of sticky rice flour, brown sugar, granulated sugar, and coconut milk. Dodol can also be made using vegetables and fruit, some dodol products from fruits namely, pineapple dodol, dodol, jackfruit, and so forth. The development of tamarind meat as the raw material for dodol will create a different taste in dodol, which is a combination of sour and sweet taste, with the dodol-specific chewy texture. In this study, researchers used an experimental method to produce dodol tamarind which has a good color, texture, taste, aroma, and appearance. To find out the panelist's response regarding Javan dodol, researchers conducted an organoleptic test through a hedonic quality test and a hedonic test involving 30 trained panelists. By developing these innovations, it is expected to introduce that tamarind meat can not only be used as a spice in herbal drinks and beverages, but can be enjoyed in the form of dodol snacks. The results showed that the use of tamarind meat has the feasibility as a raw material for making dodol. Research and development on dodol using tamarind meat produces a snack that is suitable for consumption because it produces dodol that has good taste, chewy texture, pleasant aroma, natural color, and attractive appearance.
\end{abstract}

Keywords: Tamarind, Dodol, Snack, organoleptic test 


\section{PENDAHULUAN}

Camilan atau snack sudah tidak asing lagi bagi sebagian besar masyarakat. Makanan yang memiliki cita rasa yang nikmat dengan berbagai variasi rasa, serta mudah untuk dikonsumsi ini membuat camilan sangat digemari masyarakat dari berbagai latar belakang usia. Tidak heran hingga saat ini banyak produsen makanan yang berlomba-lomba untuk menciptakan dan memasarkan camilan yang dapat menarik minat masyarakat. Dalam (Nurhayati, Lasmanawati, 2012) snack atau cemilan adalah jenis makanan yang disajikan diluar waktu makan utama. Snack dapat membantu memenuhi kebutuhan kalori, selain yang diperoleh dari makanan utama. Menurut (Ginting \& Hadi, 2012) perkembangan snack/camilan di Indonesia kian berkembang dikarenakan kebiasaan snacking/ngemil yang merupakan salah satu budaya kehidupan di Indonesia. Hal ini dapat diilihat ketika masyarakat Indonesia mengadakan jamua di rumahnya, tuan rumah akan menyajikan beragam makanan ringan/snack food kepada tamu sebagai bentuk penghormatan. Begitu pula dalam acara formal seperti rapat, mulai rapat kantor bahkan sampai rapat pemerintah sering juga disajikan snacks food untuk peserta rapat.

Asam seringkali tumbuh di kebun-pekarangan rumah pada daerah-daerah di Pulau Jawa. Asam seringkali ditanam di pekarangan rumah, terutama pada tepi-tepi jalan sebagai tanaman pembatas dan peneduh. Pohon asam relatif tahan terhadap lingkungan kering dan dapat tumbuh selama ratusan tahun. Asam kaya akan karbohidrat, kalori, protein, lemak, kalsium, zat besi, vitamin A, vitamin B, vitamin C, air, fosfor dan senyawa lainnya yang bermanfaat bagi tubuh manusia. Asam jawa banyak dimanfaatkan sebagai pengobatan tradisional, dan banyak dimanfaatkan karena memiliki sifat antibakteri, antikapang, serta mengandung antioksidan yang cukup tinggi (Puspitasari, 2014). Secara empirik, asam digunakan dalam pengobatan sariawan. Daun sinom digunakan sebagai bahan pembuatan minuman penyegar (sinom), obat rematik, serta mengobati demam dan batuk. Biji asam yang telah dijadikan tepung dapat digunakan untuk mengobati diare (Hakim, 2015). Sebelum matang daging asam jawa berwarna putih kehijauan dan memiliki rasa yang sangat asam. Saat sudah matang, daging asam jawa akan berubah warna menjadi merah kecolatan hingga kehitaman dan memiliki rasa asam sedikit manis dan lengket. Buah asam yang masih muda rasanya sangat masam, biasanya digunakan untuk bumbu sayur asam dan sambal rujak. Jika buahnya sudah matang bisa bisa disimpan lama dengan dikeringkan dibawah sinar matahari, sebelumnya asam juga harus dikupas dahulu. Selain digunakan sebagai bumbu, asam dapat 
menghilangkan bau amis pada ikan. Rasa asam pada asam jawa dapat menambahkan rasa segar pada makanan. (Waluyani, 2012).

Menurut (Balai Penelitian Tanaman Industri dan Penyegar, 2011) Indonesia memiliki pertanaman asam yang luas di Provinsi Nusa Tenggara Timur yang tersebar di Kabupaten Timor Tengah Selatan (TTS), Timor Tengah Utara (TTU), Manggarai dan Manggarai Timur, yang sangat potensial sebagai penghasil tepung biji asam. Berdasarkan data Dinas Perkebunan dan Kehutanan Provinsi Nusa Tenggara Timur, di provinsi tersebut terdapat potensi sebanyak 3.000 ton biji asam per tahun atau setara dengan 2.700 ton tepung biji asam per tahun. Dari jumlah potensi tersebut sebanyak $80 \%$ diperoleh dari pertanaman asam jawa dari Kabupaten Timor Tengah Selatan yang mempunyai pertanaman terluas di Provinsi Nusa Tenggara Timur. Hampir sebagian besar hutan di Kabupaten Timor Tengah Selatan didominasi oleh pohon asam, dimana pohon asam tumbuh dengan sendirinya tanpa adanya unsur kesengajaan untuk menanamnya. Selama ini masyarakat Timor Tengah Selatan mengolah buah asam menjadi asam kawak, dengan produksi asam kawak mencapai 2.000 - 3.000 ton per tahun.

Dodol merupakan camilan tradisional yang sudah tidak asing lagi dikalangan masyarakat Indonesia. Dodol merupakan camilan tradisional yang terbuat dari campuran tepung ketan putih, gula merah dan santan kelapa, lalu dididihkan hingga mengental, dan tidak lengket pada panci (Nasaruddin et al., 2012). Apabila telah dingin, pasta akan menjadi padat, dan kenyal. Menurut (Badan Penelitian dan Pengembangan Pertanian, 2012), dodol bisa disajikan kapan saja, baik itu untuk cemilan (kudapan) atau sajian kue untuk tamu. Dodol juga biasanya disajikan pada acara tertentu, seperti perayaan hari raya besar, arisan, maupun perayaan imlek. Selain itu, dodol juga sering dijadikan alternatif oleh-oleh atau buah tangan khas daerah. Dodol memiliki rasa yang bervariasi, seperti durian, nanas, dan nangka, serta cara pembuatan yang beragam pula. Dodol yang baik dan lezat, harus berwarna tua, mengilat dan pekat. Jika sudah dikemas, biasanya dodol bisa bertahan cukup lama. Bahan untuk membuat dodol terdiri dari bahan baku dan bahan tambahan. Bahan baku pada pembuatan dodol asam jawa adalah buah asam jawa, dan bahan tambannya adalah tempung ketan, gula merah, gula pasir dan santan. Interaksi antara tepung beras ketan, gula, dan santan kelapa selama proses pengolahan pada suhu tinggi menghasilkan dodol dengan karakterisitik organoleptik yang khas yaitu warna coklat, rasa manis, dan tekstur yang lengket (Lukito, Maharani Sandiana, Giyarto, 2017). Indikator kerusakan dodol dapat dilihat dari segi warna yang mulai berubah, aroma tengik, dan pertumbuhan kapang (Vindayanti, 2012). 
Menurut (Hakim, 2015), asam jawa adalah tanaman yang tumbuh di kebun-pekarangan rumah pada daerah-daerah di Pulau Jawa. Asam kaya akan karbohidrat, kalori, protein, lemak, kalsium, zat besi, vitamin A,vitamin B, vitamin C, air, fosfor dan senyawa lainnya yang bermanfaat bagi tubuh manusia. Secara empirik, asam digunakan dalam pengobatan sariawan. Daun sinom digunakan sebagai bahan pembuatan minuman penyegar (sinom), obat rematik, serta mengobati demam dan batuk. Biji asam yang telah dijadikan tepung dapat digunakan untuk mengobati diare. Sebelum matang daging asam jawa berwarna putih kehijauan dan memiliki rasa yang sangat asam. Saat sudah matang, daging asam jawa akan berubah warna menjadi merah kecolatan hingga kehitaman dan memiliki rasa asam sedikit manis dan lengket. Buah asam yang masih muda rasanya sangat masam, biasanya digunakan untuk bumbu sayur asam dan sambal rujak. Jika buahnya sudah matang bisa bisa disimpan lama dengan dikeringkan dibawah sinar matahari, sebelumnya asam juga harus dikupas dahulu. Selain digunakan sebagai bumbu, asam dapat menghilangkan bau amis pada ikan. Rasa asam pada asam jawa dapat menambahkan rasa segar pada makanan. (Waluyani, 2012).

Menurut (Nasaruddin et al., 2012), Dodol merupakan camilan tradisional yang terbuat dari campuran tepung ketan putih, gula merah dan santan kelapa, lalu dididihkan hingga mengental, dan tidak lengket. Menurut (Badan Penelitian dan Pengembangan Pertanian, 2012), dodol bisa disajikan kapan saja, baik itu untuk cemilan (kudapan) atau sajian kue untuk tamu. Dodol juga biasanya disajikan pada acara tertentu, seperti perayaan hari raya besar, arisan, maupun perayaan imlek. Selain itu, dodol juga sering dijadikan alternatif oleh-oleh atau buah tangan khas daerah. Dodol memiliki rasa yang bervariasi, seperti durian, nanas, dan nangka, serta cara pembuatan yang beragam pula. Dodol yang baik dan lezat, harus berwarna tua, mengilat dan pekat. Jika sudah dikemas, biasanya dodol bisa bertahan cukup lama. Bahan untuk membuat dodol terdiri dari bahan baku dan bahan tambahan. Bahan baku pada pembuatan dodol asam jawa adalah buah asam jawa, dan bahan tambannya adalah tempung ketan, gula merah, gula pasir dan santan.

Menurut (Nurhayati, Lasmanawati, 2012), snack atau camilan adalah Jenis makanan yang disajikan diluar waktu makan utama. Snack dapat membantu memenuhi kebutuhan kalori, selain yang diperoleh dari makanan utama

Menurut (Matson, 2018) tepung beras ketan dibuat menggunakan beras ketan yang kebanyakan berbutir pendek. Jenis beras ini umum di Asia. Kadang-kadang dikenal sebagai tepung beras ketan atau tepung ketan. Tepung ini sama seperti tepung lainnya yang berwarna putih dan memiliki kemampuan penyerapan tinggi. Selain itu, tepung bisa tahan suhu dingin 
yang ekstrem tanpa harus takut tepung ini pecah. Kemudian, tepung ini juga merupakan tepung yang bebas gluten. Menurut (Imanningsih, 2012) tepung beras ketan adalah tepung yang terbuat dari kultivar beras yang mengandung sejumlah besar amilopektin. Pada kue-kue tradisional Indonesia, tepung ketan digunakan untuk menghasilkan produk-produk yang kenyal dan agak lengket, seperti kelepon, lumpang, bugis dan kue lapis.

Menurut (Beck, 2018) gula kelapa (gula aren atau gula merah) telah menjadi alternatif populer untuk gula putih karena rasanya dan manfaat kesehatan yang dirasakan. Ini juga dipandang lebih alami, atau melalui proses yang lebih dikit, dibandingkan gula putih. Gula kelapa dibuat dari getah kuncup bunga dari pohon kelapa. Getahnya direbus di atas api untuk menguapkan sebagian besar kandungan airnya. Produk itu yang akhirnya akan menjadi gula kelapa, yang berwarna karamel dengan rasa dan aromanya yang khas.

Menurut (The Sugar Association, 2017), gula memiliki banyak fungsi lain dalam memasak dan memanggang. Gula berkontribusi dalam pembentukan tekstur dan memberikan warna kecoklatan dalam produk bakery. Ragi membutuhkan gula untuk mengatur proses fermentasi yang menjadikan roti dapat mengembang. Gula menambahkan cita rasa pada es krim dan produk bakery, sebagai pengawet alami pada selai dan buah, dan menambahkan cita rasa pada produk minuman. Makanan nonsweet seperti, saus salad, saus, dan bumbu, gula meningkatkan rasa dan menyeimbangkan keasaman alami produk berbasis tomat dan cuka.

Menurut (Tipvarakarnkoon, 2009), santan diperoleh dari proses pemarutan daging kelapa putih dan kemudian memeras daging kelapa yang telah diparut untuk mendapatkan cairan santan segar yang pada umumnya mengandung $34 \%$ lemak.

\section{METODE}

Penelitian ini menggunakan metode eksperimen yang mana biasanya berkaitan dengan pendekatan deduktif. Menurut (Sekaran, Bougie, 2016) tujuan dari metode eksperimen ini adalah untuk mempelajari sebab akibat yang terjadi antara variabel. Desain eksperimental sesuai untuk menjawab pertanyaan penelitian yang bersifat eksplarasi dan naratif.

Menurut (Sekaran \& Bougie, 2016), Populasi mengacu pada seluruh kelompok orang, peristiwa, atau hal-hal menarik yang ingin diselidiki oleh peneliti. Populasi dalam penelitian ini adalah camilan. Sampel adalah bagian dari populasi. Terdiri dari beberapa anggota yang dipilih dari populasi, dengan kata lain tidak semua elemen pada populasi dapat dijadikan sampel (Sekaran \& Bougie, 2016). Sampel penelitian ini adalah dodol untuk dikembangkan menjadi dodol asam jawa. 
Menurut (Nasaruddin et al., 2012), Dodol merupakan camilan tradisional yang terbuat dari campuran tepung ketan putih, gula merah dan santan kelapa, lalu dididihkan hingga mengental, dan tidak lengket. Ada pula beragam produk dodol yang terbuat dari buah, hingga sayuran. Disni peneliti menggukan daging asam jawa untuk menambah varian pada dodol dan mengembangkan penggunaan daging asam jawa sehingga dapat dikonsumsi oleh berbagai kalangan.

\section{Teknik Pengumpulan Data}

Menurut (Sekaran \& Bougie, 2016), Data dapat diperoleh dari sumber data primer dan data sekunder. Data primer merupakan data yang mengacu pada informasi yang diperoleh langsung (dari tangan pertama) oleh peneliti terkait dengan variabel ketertarikan untuk tujuan tertentu dalam studi. Data primer dalam penelitian ini diperoleh melalui penyebaran kuesioner uji organoleptik untuk memperoleh informasi dari responden mengenai tingkat kesukaan dodol asam jawa. Pada kuesioner yang disebar terdiri dari dua jenis variasi dodol asam jawa dimana pada setiap variasi terdapat lima aspek yaitu aspek aroma, aspek rasa, aspek warna dan aspek tekstur. Responden dapat menilai setiap aspek dengan bantuan skala dan dilakukan interview singkat terhadap panelis untuk memberikan tanggapan pribadi ataupun dapat dituliskan pada kolom yang disediakan. Data sekunder merupakan data yang sudah ada dan tidak perlu dikumpulkan oleh peneliti. Sumber data sekunder dapat diperoleh melalui studi kepustakaan atau studi literatur. Peneliti mengumpulkan informasi yang berhubungan dengan permasalahan yang diteliti dari buku, jurnal artikel, laporan pemerintah, koran dan media elektronik (Internet).

Pengukuran penilaian dalam penelitian ini menggunakan pendekatan data kuantitatif dengan instrumen penelitian penyebaran kuesioner. Kuesioner berupa penelitian uji organoleptik untuk menilai aspek aroma, rasa, warna, tekstur, dan penampilan. Menurut (Lawless \& Heymann, 2010) uji organoleptik atau evaluasi sensori didefinisikan sebagai metode untuk membangkitakan, mengukur, menganalisis, dan menginterprtasikan responsrespons yersebut terhadap produk-produk yang dirasakan melalui indera penglihatan, bau, sentuhan, rasa, dan pendengaran. Uji oraganoleptik dilakukan kepada 30 panelis terlatih. Pengukuran nilai dalam kuesioner digunakan jenis skala ordinal. Menurut (Sekaran \& Bougie, 2016), skala ordinal tidak hanya mengategorikan variabel-variabel dalam suatu cara untuk menunjukkan perbedaan di antara berbagai kategori, tetapi juga mengurutkannya menjadi beberapa cara yang bermakna. Skala ordinal memberikan beberapa informasi tambahan dengan mengurutkan tingkatan kategori nominal (dari terbaik ke terburuk; dari pertama ke 
terakhir), sehingga pada penelitian ini nilai pengukuran dalam skala pengukuran hedonik dan mutu hedonik dapat dilihat pada tabel di bawah ini.

Tabel 1. Skala Ordinal Dalam Penilaian Uji Hedonik dan Mutu Hedonik

\begin{tabular}{lll}
\hline $\begin{array}{l}\text { Skala } \\
\text { Ordinal }\end{array}$ & $\begin{array}{l}\text { Skala } \\
\text { Hedonik }\end{array}$ & $\begin{array}{l}\text { Skala Mutu } \\
\text { Hedonik }\end{array}$ \\
\hline 1 & Sangat & Sangat \\
& Tidak & Tidak Baik \\
& Suka & \\
2 & Tidak & Tidak Baik \\
& Suka & \\
3 & Agak Suka & Agak Baik \\
4 & Suka & Baik \\
5 & Sangat & Sangat Baik \\
& Suka & \\
\hline
\end{tabular}

Sumber: Sekaran \& Bougie (2016)

\section{Teknik Analisis Data}

Uji kesukaan atau uji hedonik dilakukan untuk mengetahui hasil perbedaan aspekaspek yang telah ditentukan berdasarkan dua varian dodol, yaitu dodol asam jawa dan dodol mix. Data yang diperoleh melalui kuesioner kemudian dihitung untuk mengetahui rata-rata dari kelima aspek yaitu aroma, rasa, warna, tekstur, dan penampilan. Uji Friedman adalah alternatif non-parametrik untuk One-Way ANOVA dengan pengukuran berulang. Metode ini digunakan unutk menguji perbedaan antara kelompok variabel independen ketika variabel dependen yang diukur adalah ordinal. Uji friedman pada data peringkat relatif kuat dan dapat diaplikasikan pada data apa saja, dimana semua produk dilihat oleh semua panelis, yaitu adanya peringkat lengkap yang diberikan oleh setiap peserta. Tes Friedman sangat sensitif terhadap pola urutan peringkat yang konsisten. Statistik yang dihitung dibandingkan ke nilai chi-square yang tergantung pada jumlah produk dan jumlah panelis.

\section{HASIL DAN PEMBAHASAN}

Pada bagian ini peneliti akan melampirkan tabel hasil olahan data dari panelis dengan menggunakan pengukuran uji hedonik dan uji mutu hedonik pada produk dodol asam jawa. Terdapat dua jenis varian dodol, yaitu dodol asam jawa dan dodol mix, dengan lima aspek penilaian berupa rasa, tekstur, aroma, warna, dan penampilan. 
Tabel 2. Tabel Frekuensi Uji Hedonik Dodol Asam Jawa

\begin{tabular}{|c|c|c|c|}
\hline \multicolumn{4}{|c|}{ ASAM JAWA } \\
\hline \multirow{6}{*}{ Rasa } & Skala & $\mathrm{N}$ & $\%$ Total $\mathrm{N}$ \\
\hline & 1 & 0 & $0 \%$ \\
\hline & 2 & 0 & $0 \%$ \\
\hline & 3 & 9 & $30.00 \%$ \\
\hline & 4 & 9 & $30.00 \%$ \\
\hline & 5 & 12 & $40.00 \%$ \\
\hline Total & & 30 & $100.00 \%$ \\
\hline \multirow{6}{*}{ Tekstur } & Skala & $\mathrm{N}$ & $\%$ Total N \\
\hline & 1 & 0 & $0 \%$ \\
\hline & 2 & 0 & $0 \%$ \\
\hline & 3 & 5 & $16.70 \%$ \\
\hline & 4 & 18 & $60.00 \%$ \\
\hline & 5 & 7 & $23.30 \%$ \\
\hline Total & & 30 & $100.00 \%$ \\
\hline \multirow{6}{*}{ Aroma } & Skala & $\mathrm{N}$ & $\%$ Total N \\
\hline & 1 & 0 & $0 \%$ \\
\hline & 2 & 1 & $3.30 \%$ \\
\hline & 3 & 4 & $13.30 \%$ \\
\hline & 4 & 14 & $46.70 \%$ \\
\hline & 5 & 11 & $36.70 \%$ \\
\hline Total & & 30 & $100.00 \%$ \\
\hline \multirow{6}{*}{ Warna } & Skala & $\mathrm{N}$ & $\%$ Total N \\
\hline & 1 & 0 & $0 \%$ \\
\hline & 2 & 0 & $0 \%$ \\
\hline & 3 & 4 & $13.30 \%$ \\
\hline & 4 & 20 & $66.70 \%$ \\
\hline & 5 & 6 & $20.00 \%$ \\
\hline Total & & 30 & $100.00 \%$ \\
\hline \multirow{6}{*}{ Penampilan } & Skala & $\mathrm{N}$ & $\%$ Total N \\
\hline & 1 & 0 & $0 \%$ \\
\hline & 2 & 0 & $0 \%$ \\
\hline & 3 & 8 & $26.70 \%$ \\
\hline & 4 & 14 & $46.70 \%$ \\
\hline & 5 & 8 & $26.70 \%$ \\
\hline Total & & 30 & $100.00 \%$ \\
\hline
\end{tabular}

Sumber: Data Analisis 2019

Dari tabel di atas dapat dilihat jumlah dan persentase uji hedonik terhadap dodol asam jawa. Respons dari total 30 panelis sangat beragam, dimulai dari aspek aroma yang mana 
mayoritas panelis memilih skala 5 yang berarti "sangat suka" dengan total pesentase $\mathrm{N}$ sebesar $40.0 \%$, diikuti dengan skala 3 dan 4 yang sama-sama mendapatkan respons sebesar 30.0\%. Dapat disimpulkan bahwa rasa dodol asam jawa disukai dan dapat diterima. Dikarenakan adanya penambahan gula pada dodol asam jawa sehingga rasa asam dari asam jawa dapat menjadi netral.

Pada aspek tekstur, skala 4 yang berarti "suka" mendapatkan respons tertinggi yaitu sebesar $60.0 \%$, dan diikuti dengan skala 3 yang berarti "agak suka" sebesar 16.7\% dan skala 5 sebesar 23.3\%. Dapat disimpulkan bahwa tekstur dari dodol asam jawa sudah sesuai dengan dodol pada umumnya yang bertekstur kenyal.

Selanjutnya aspek aroma dimana terdapat 3.3\% panelis yang menilai dengan skala 2 yang berarti "tidak suka", diikuti dengan skala 3 sebesar $13.3 \%$, skala 4 sebesar $46.7 \%$, dan skala 5 sebesar 36.7\%. Dapat disimpulkan bahwa aroma dari dodol asam jawa dapat diterima. Dikarenakan, adanya penggunaan gula merah pada adonan dodol asam jawa, sehingga ada perpaduan aroma gula merah yang khas dan aroma asam dari asam jawa.

Pada aspek warna respon dari panelis cukup baik dimana sebanyak $13.3 \%$ memilih skala 3, 66.7\% memilih skala 4, dan 20.0\% memilih skala 5. Dengan demikian dapat disimpulkan bahwa warna pada dodol asam jawa dapat diterima, karena dodol asam jawa memiliki warna coklat pekat alami yang didapat dari daging asam jawa dan gula merah.

Aspek penilaian terakhir yaitu penampilan mendapatkan respons dengan skala 3 sebanyak 26.7\%, skala 4 sebanyak $46.7 \%$, dan skala 5 sebanyak 26.7\%. Dengan demikian dapat disimpulkan bahwa penampilan dari dodol asam jawa dapet diterima karena dodol asam jawa dikemas dalam ukuran kecil dan dibungkus menggunakan kertas minyak yang bermotif. Sehingga tampilan dodol asam jawa terlihat menarik.

Tabel 3. Tabel Frekuensi U ji Hedonik Dodol Mix

\begin{tabular}{|c|c|c|c|}
\hline \multicolumn{4}{|c|}{ DODOL MIX } \\
\hline \multirow{6}{*}{ Rasa } & Skala & $\mathrm{N}$ & $\%$ Total $\mathrm{N}$ \\
\hline & 1 & 0 & $0 \%$ \\
\hline & 2 & 0 & $0 \%$ \\
\hline & 3 & 2 & $6.70 \%$ \\
\hline & 4 & 10 & $33.30 \%$ \\
\hline & 5 & 18 & $60.00 \%$ \\
\hline Total & & 30 & $100.00 \%$ \\
\hline \multirow{4}{*}{ Tekstur } & Skala & $\mathrm{N}$ & $\%$ Total $\mathrm{N}$ \\
\hline & 1 & 0 & $0 \%$ \\
\hline & 2 & 0 & $0 \%$ \\
\hline & 3 & 4 & $13.30 \%$ \\
\hline
\end{tabular}




\begin{tabular}{|c|c|c|c|}
\hline & 4 & 10 & $33.30 \%$ \\
\hline & 5 & 16 & $53.30 \%$ \\
\hline Total & & 30 & $100.00 \%$ \\
\hline \multirow{6}{*}{ Aroma } & Skala & $\mathrm{N}$ & $\%$ Total N \\
\hline & 1 & 0 & $0 \%$ \\
\hline & 2 & 0 & $0 \%$ \\
\hline & 3 & 6 & $20.00 \%$ \\
\hline & 4 & 15 & $50.00 \%$ \\
\hline & 5 & 9 & $30.00 \%$ \\
\hline Total & & 30 & $100.00 \%$ \\
\hline \multirow{6}{*}{ Warna } & Skala & $\mathrm{N}$ & $\%$ Total N \\
\hline & 1 & 0 & $0 \%$ \\
\hline & 2 & 0 & $0 \%$ \\
\hline & 3 & 5 & $16.70 \%$ \\
\hline & 4 & 14 & $46.70 \%$ \\
\hline & 5 & 11 & $36.70 \%$ \\
\hline Total & & 30 & $100.00 \%$ \\
\hline \multirow{6}{*}{ Penampilan } & Skala & $\mathrm{N}$ & $\%$ Total N \\
\hline & 1 & 0 & $0 \%$ \\
\hline & 2 & 0 & $0 \%$ \\
\hline & 3 & 5 & $16.70 \%$ \\
\hline & 4 & 12 & $40.00 \%$ \\
\hline & 5 & 13 & $43.30 \%$ \\
\hline Total & & 30 & $100.00 \%$ \\
\hline
\end{tabular}

Sumber: Data Analisis 2019

Pada tabel di atas terlampir data hasil uji hedonik terhadap dodol mix untuk mengetahui tingkat kesukaan panelis terhadap dodol mix. Dimulai dari aspek rasa, tidak ada panelis yang memberikan penilaian dengan skala 1 dan 2. Terdapat sebanyak 6.7\% panelis memilih skala 3, 33\% untuk skala 4, dan yang terbanyak adalah skala 5 yang berarti "sangat suka" dengan persentase sebesar 60\%. dapat disimpulkan bahwa rasa pada dodol mix dapat diterima dan sangat disukai. Perpaduan antara dua jenis dodol, yaitu dodol asam jawa dan dodol orignial membuat memberikan dua cita rasa yang berbeda. Dodol asam jawa memiliki rasa asam dari daging asam jawa dan dodol original memiliki rasa manis yang gurih dari gula merah dan santan yang lebih pekat dibandingkan dodol asam jawa.

Aspek kedua yaitu tekstur mendapatkan penilaian dengan skala 3 sebanyak 13.3\%, skala 4 sebanyak 33.3\%, dan skala 5 sebanyak 53.3\%. Dapat disimpulkan bahwa tekstur dodol mix dapat diterima, sebab dodol mix memiliki tekstur yang kenyal sama seperti dodol pada umumnya. Tekstur kenyal tersebut disebabkan oleh penggunaan tepung ketan pada adonan dodol. 
Untuk aspek aroma, mayoritas panelis memilih skala 4 sebanyak 50\%. aroma pada dodol mix disukai karena kedua jenis dodol yaitu dodol asam jawa dan dodol orignial samasama menggunakan gula merah, sehingga aroma dari gula merah akan terasa lebih mencolok. Begitu juga dengan aspek warna dan penampilan dengan penilaian tertinggi pada skala 4 yaitu sebanyak $46.7 \%$ dan $40 \%$. Warna dan penampilan pada ddol mix dapat diterima, dikarenakan dodol mix memiliki dua lapisan warna, yaitu warna coklat gelap dari dodol asam jawa dan warna coklat terang dari dodol original, sehingga warna dari dodol mix terlihat menarik. Dodol mix juga dikemas menggunakan kertas minyak bermotif untuk meningkatkan penampilan dari dodol mix.

Tabel 4. Tabel Frekuensi Uji Mutu Hedonik Dodok Asam Jawa

\begin{tabular}{|c|c|c|c|}
\hline \multicolumn{4}{|c|}{ ASAM JAWA } \\
\hline \multirow{6}{*}{ Rasa } & Skala & $\mathrm{N}$ & $\%$ Total N \\
\hline & 1 & 0 & $0 \%$ \\
\hline & 2 & 0 & $0 \%$ \\
\hline & 3 & 6 & $20.0 \%$ \\
\hline & 4 & 16 & $53.3 \%$ \\
\hline & 5 & 8 & $26.7 \%$ \\
\hline \multirow[t]{2}{*}{ Total } & & 30 & $100.00 \%$ \\
\hline & Skala & $\mathrm{N}$ & $\%$ Total N \\
\hline \multirow{5}{*}{ Tekstur } & 1 & 0 & $0 \%$ \\
\hline & 2 & 0 & $0 \%$ \\
\hline & 3 & 6 & $20.0 \%$ \\
\hline & 4 & 10 & $33.3 \%$ \\
\hline & 5 & 14 & $46.7 \%$ \\
\hline \multirow[t]{2}{*}{ Total } & & 30 & $100.00 \%$ \\
\hline & Skala & $\mathrm{N}$ & $\%$ Total N \\
\hline \multirow{5}{*}{ Aroma } & 1 & 0 & $0 \%$ \\
\hline & 2 & 1 & $3.30 \%$ \\
\hline & 3 & 3 & $10.0 \%$ \\
\hline & 4 & 16 & $53.3 \%$ \\
\hline & 5 & 10 & $33.3 \%$ \\
\hline \multirow[t]{2}{*}{ Total } & & 30 & $100.00 \%$ \\
\hline & Skala & $\mathrm{N}$ & $\%$ Total N \\
\hline \multirow{5}{*}{ Warna } & 1 & 0 & $0 \%$ \\
\hline & 2 & 0 & $0 \%$ \\
\hline & 3 & 2 & $6.7 \%$ \\
\hline & 4 & 23 & $76.7 \%$ \\
\hline & 5 & 5 & $16.7 \%$ \\
\hline \multicolumn{2}{|l|}{ Total } & 30 & $100.00 \%$ \\
\hline
\end{tabular}




\begin{tabular}{|c|c|c|c|}
\hline \multirow{6}{*}{ Penampilan } & Skala & $\mathrm{N}$ & $\%$ Total N \\
\hline & 1 & 0 & $0 \%$ \\
\hline & 2 & 3 & $10.0 \%$ \\
\hline & 3 & 7 & $23.3 \%$ \\
\hline & 4 & 12 & $40.0 \%$ \\
\hline & 5 & 8 & $26.7 \%$ \\
\hline Total & & 30 & $100.00 \%$ \\
\hline
\end{tabular}

Pada tabel di atas dapat dilihat bahwa mayoritas panelis memberikan penilaian pada skala 3, 4, dan 5. Pada aspek rasa, panelis paling banyak menilai denga skala 4, yaitu sebanyak 53.3\%, yang berat rasa dari dodol asam jawa memiliki mutu baik. Pada aspek tektur skala 5 mendapatkan respons tertinggi yaitu sebanyak $46.7 \%$, yang berarti tekstur dari dodol asam jawa sesuai dengan tekstur dodol pada umumnya. Sedangkan pada aspek aroma terdapat 1 panelis yang memilih skala 2, dan selebihnya panelis memilih skala 3 sebanyak $10 \%$, skala 4 sebanyak 53.3\%, dan skala 5 sebanyak 33.3\%. Dengan demikian dapat diartikan bahwa aroma dodol asam jawa memiliki mutu aroma yang baik. Untuk aspek warna dan penampilan skala 4 menjadi skala penilaian terbanyak yang dipilih oleh panelis yaitu sebesar $76.7 \%$ dan 40\%. Dengan demikian dapat disimpulkan bahwa warna pada dodol asam jawa memiliki mutu yang baik, yaitu berwarna coklat gelap alami. Disamping itu penampilan dari dodol asam jawa juga memiliki mutu pengemasan dan tampilan yang baik.

Tabel 5. Tabel Frekuensi Uji Mutu Hedonik Dodol Mix

\begin{tabular}{|c|c|c|c|}
\hline \multicolumn{4}{|c|}{ DODOL MIX } \\
\hline \multirow{6}{*}{ Rasa } & Skala & $\mathrm{N}$ & $\%$ Total N \\
\hline & 1 & 0 & $0 \%$ \\
\hline & 2 & 0 & $0 \%$ \\
\hline & 3 & 2 & $6.70 \%$ \\
\hline & 4 & 13 & $43.3 \%$ \\
\hline & 5 & 15 & $50.0 \%$ \\
\hline \multicolumn{2}{|l|}{ Total } & 30 & $100.00 \%$ \\
\hline \multirow{6}{*}{ Tekstur } & Skala & $\mathrm{N}$ & $\%$ Total N \\
\hline & 1 & 0 & $0 \%$ \\
\hline & 2 & 0 & $0 \%$ \\
\hline & 3 & 1 & $3.3 \%$ \\
\hline & 4 & 12 & $40.0 \%$ \\
\hline & 5 & 17 & $56.7 \%$ \\
\hline \multicolumn{2}{|l|}{ Total } & 30 & $100.00 \%$ \\
\hline \multirow{3}{*}{ Aroma } & Skala & $\mathrm{N}$ & $\%$ Total $\mathrm{N}$ \\
\hline & 1 & 0 & $0 \%$ \\
\hline & 2 & 0 & $0 \%$ \\
\hline
\end{tabular}




\begin{tabular}{|c|c|c|c|}
\hline & 3 & 4 & $13.3 \%$ \\
\hline & 4 & 13 & $43.3 \%$ \\
\hline & 5 & 13 & $43.3 \%$ \\
\hline Total & & 30 & $100.00 \%$ \\
\hline \multirow{6}{*}{ Warna } & Skala & $\mathrm{N}$ & $\%$ Total N \\
\hline & 1 & 0 & $0 \%$ \\
\hline & 2 & 1 & $3.3 \%$ \\
\hline & 3 & 3 & $10.0 \%$ \\
\hline & 4 & 14 & $46.7 \%$ \\
\hline & 5 & 12 & $40.0 \%$ \\
\hline Total & & 30 & $100.00 \%$ \\
\hline \multirow{6}{*}{ Penampilan } & Skala & $\mathrm{N}$ & $\%$ Total N \\
\hline & 1 & 0 & $0 \%$ \\
\hline & 2 & 0 & $0 \%$ \\
\hline & 3 & 7 & $23.3 \%$ \\
\hline & 4 & 10 & $33.3 \%$ \\
\hline & 5 & 13 & $43.3 \%$ \\
\hline Total & & 30 & $100.00 \%$ \\
\hline
\end{tabular}

Sumber: Data Analisis 2019

Pada tabel di atas dapat dilihat bahwa mayoritas panelis memberikan penilaian pada skala 3, 4, dan 5. Pada aspek rasa, panelis paling banyak menilai denga skala 5, yaitu sebanyak 50\%, yang berati rasa dari dodol mix memiliki mutu yang sangat baik. Pada aspek tektur skala 5 mendapatkan respons tertinggi yaitu sebanyak $56.7 \%$, yang berarti tekstur dari mix sesuai dengan tekstur dodol pada umumnya, yaitu kenyal. Sedangkan pada aspek aroma persentase panelis yang memilih skala 4 dan skala 5 sama-asam sebanyak 43.3\%. Dengan demikian dapat diartikan bahwa aroma dodol mix memiliki mutu aroma yang baik. Untuk aspek warna skala 4 menjadi skala penilaian terbanyak yang dipilih oleh panelis yaitu sebesar 46.7\%. Dan yang terakhir adalah aspek penampilan dengan persentase tertinggi sebesar 43.3\% pada skala 4. Dengan demikian dapat disimpulkan bahwa warna pada dodol mix memiliki mutu yang baik, yaitu berwarna coklat gelap dan coklat terang, yang dihasilkan dari penggunaan bahan alami, seperti, asam jawa dan gula merah. Disamping itu penampilan dari dodol mix juga memiliki mutu pengemasan dan tampilan yang baik.

Pada aspek rasa tingkat kesukaan dodol asam jawa dan dodol mix paling tinggi berada pada skala penilaian 5 yang berarti "sangat suka" dengan persentase sebesar 40\% pada varian dodol asam jawa dan $60 \%$ untuk dodol mix.

Faktor yang memengaruhi pesentase pada dodol mix lebih tinggi dibandingkan dodol asam jawa dalam aspek rasa adalah dikarenakan dodol mix merupakan perpaduan antara dodol asam jawa dan dodol original, sehingga rasa dodol akan terasa lebih gurih. Selain itu 
penambahan potongan kacang tanah memberikan cita rasa tambahan. Dodol original sendiri memiliki komposisi santan dan gula merah yang lebih banyak dibandingkan dodol asam jawa, yang mana sesuai dengan teori yang disampaikan (Tipvarakarnkoon, 2009) bahwa santan diperoleh dari proses pemarutan daging kelapa putih dan kemudian memeras daging kelapa yang telah diparut untuk mendapatkan cairan santan segar yang pada umumnya mengandung $34 \%$ lemak. Kandungan lemak pada santan memberikan rasa yang gurih ada setiap makanan. Sedangkan menurut (Beck, 2018) gula merah sendiri memiliki rasa manis yang khas, sehingga dodol mix memiliki rasa yang netral antara asam, manis dan gurih. Pada aspek tekstur tingkat kesukaan tertinggi terhadap tekstur dodol asam jawa berada pada skala 4 yang berarti "suka" dan dengan presesntase sebesar 60\%. Tingkat kesukaan tertinggi terhadap dodol mix berada pada skala penlinaian 5 yang berarti "sangat suka" dengan persentase sebesar 53.3\%. Dari perbedan persentase penilaian tersebut dapat disimpulkan bahwa tekstur dodol mix lebih disukai dibandingkan dengan dodol mix.

Faktor yang mempengaruh hasil penilaian tersebut adalah perpaduan dari dodol asam jawa dan dodol original memberikan tekstur yang berbeda. Dodol asam jawa mengandung komposisi gula yang lebih banyak sehingga tekstur yang lebih kenyal dan ditambah lagi sedikit tekstur dari daging asam jawa. Sepeti yang dikatakan oleh (The Sugar Association, 2017) bahwa gula dapat memberikan tekstur pada produk makanan. Penambahan kacang pada adonan dodol mix memberikan tekstur tambahan yang memberikan kesan berbeda dibandi dodol asa, jaw. Disamping itu dodol original memiliki tekstur yang lembut dimulut dan lebih padat. Sehingga ketika kedua dodol tersebut disatukan maka akan tercipta tekstur yang berbeda. aspek aroma tingkat kesukaan aroma dodol asam jawa dan dodol mix paling tinggi berada pada skala penilaian 4 yang berarti "suka" dengan persentase dodol asam jawa sebesar 46.7\% dan dodol mix sebesar 50\%. Dapat disimpulkan bahwa aroma dari dodol mix lebih disukai dibandingkan dengan dodol asam jawa.

Faktor yang mempengaruhi hasil dari penilaian tersebut adalah dodol asam jawa dan dodol mix menggunakan gula merah dalam proses pembuatannya. Seperti yang dikatakan oleh (Beck, 2018), gula merah dikenal degan aromanya yang khas dan berbau sedap. Sehingga tidak heran jika kedua jenis varian dodol tersebut disukai karena aromanya yang sedap dari penggunaan gula merah.

aspek warna tingkat kesukaan paling tinggi pada pembuatan dodol asam jawa dan dodol mix berada pada skala 4 yang berarti "suka" dengan persentase sebesar $66.7 \%$ untuk 
dodol asam jawa dan $46.7 \%$ untuk dodol mix. Dapat disimpulkan bahwa warna dodol asam jawa lebih disukai dibandingkan dodol mix.

Faktor yang memengaruhi hasil penilaian tersebut dikarenakan dodol asam jawa mengandung daging dari asam jawa sendiri yang berawarna coklat gelap, sehingga ketika dicampurkan dengan bahan lain dodol asam jawa akan menghasilkan warna coklat pekat khas dodol. Selain itu komposisi gula pasir yang lebih banyak dibandingkan dodol mix tentunya berpengaruh terhadap tampilan warna dari dodol asam jawa. Seperti yang dinyakan oleh (The Sugar Association, 2017), bahwa gula dapat menambah warna kecoklatan pada makanan.

Pada aspek penampilan tingkat kesukaan paling tinggi pada pembuatan dodol asam jawa dan dodol mix berada pada skala 4 yang berarti "suka" dan skala 5 yang berarti "sangat suka" dengan persentase sebesar $46.7 \%$ pada skala 4 dodol asam jawa dan $43.3 \%$ pada skala 5 dodol mix. Dapat disimpulkan bahwa penampilan dodol mix lebih disukai dibandingkan dodol asam jawa.

Faktor yang mempengaruhi hasil penilaian tersebut adalah perpaduan warna antara dodol asam jawa dan dodol original memberikan daya tarik yang berbeda. Karena dodol asam jawa memiliki warna yang lebih kecoklatan dibandingkan dodol original yang cenderung berawarna coklat pucat. Karena pada umumnya suatu produk dodol hanya terdiri dari satu jenis rasa dan warna, dan berbeda dengan dodol mix yang terdiri dari dua jenis dodol dan dua warna yang berbeda sehingga terlihat lebih unik.

Pada kualitas dodol asam jawa dan dodol mix berada pada skala 4 yang berarti "suka" dan skala 5 yang berarti "sangat suka" dengan persentase $53.3 \%$ pada skala 4 dodol asam jawa dan 50\% pada skala 5 dodol mix. Dengan demikian data disimpulkan peringkat kualitas pada aspek rasa trhadap dodol mix lebih baik dibandingkan dengan dodol asam jawa.

Faktor yang memengaruhi penilaian terhadap kualitas rasa pada pembuatan dodol adalah komposisi bahan yang digunakan. Dodol asam jawa mengandung lebih banyak air dan santan yang tidak begitu pekat dibandingkan dodol original sehingga rasa dari dodol asam jawa tidak segurih dodol original. Karena seperti yang dinyatakan oleh (Tipvarakarnkoon, 2009) santan mengandung lemak dan memberikan rasa gurih pada makanan. Dengan demikian dodol mix memiliki rasa yang lebih netral, anatar manis, gurih, dan asam.

Pada aspek tekstur terhadap kualitas dodol asam jawa dan dodol mix sama-sama berada pada skala 5 yang berarti "sangat baik" dengan persentase $46.7 \%$ untuk dodol asam jawa dan $56.7 \%$ untuk dodol mix. Dengan demikian data disimpulkan peringkat kualitas pada aspek tekstur trhadap dodol mix lebih baik dibandingkan dengan dodol asam jawa. 
Faktor yang mempengaruhi hasil penilaian tersebut dikarenakan kedua jenis dodol tersebut sama-sama menggunakan tepung ketan yang mengandung amilopektin yang tinggi pada pati beras ketan memberikan karakteristik thickening (mengentalkan) dan gelling (membentuk gel) (Imanningsih, 2012). Akan tetapi dodol asam jawa mengandung lebih banyak air dan gula sehingga tekstur dari dodol asam jawa cenderung lebih kenyal. Ditambah lagi dengan daging asam jawa yang sedikit bertekstur. Berbeda dengan dodol original yang memiliki komposisi air dan gula yang lebih sedikit sehingga menghasilkan tekstur yang lebih padat dan lembut. Penambahan kacang pada adonan dodol original juga memberikan tekstur berbeda. Sehingga ketika kedua jenis dodol tersebut menyatu maka akan membentuk dua tekstur yang berbeda.

Pada aspek aroma, tingkat kualitas tertinggi terhadap aroma dodol asam jawa dan dodol mix berada pada skala 4 yang berarti "baik" dengan persentase sebesar $53.3 \%$ dan skala 5 yaitu "sangat baik" dengan persentase 43.3\%. Dengan demikian dapat disipulkan bahwa kualitas aroma pada dodol mix lebih baik dibandingkan dengan dodol asam jawa.

Faktor yang memepengaruhi hasil penilaian tersebut dikarenakan dodol mix terdiri dari dua jenis dodol, yaitu dodol asam jawa dan dodol original maka penggunaan gula merah pada produk dodol mix lebih banyak dibandingkan dodol asam jawa. Menurut (Beck, 2018) gula merah memiliki aroma yang khas, dan dapat menambah aroma pada suatu produk makanan. Sehingga aroma pada dodol mix lebih mencolok dibandingkan dodol asam jawa. Tingkat penilaian tertinggi terhadap kualitas dodol asam jawa dan dodo mix berada pada skala 4 yang berarti "baik" dengan masing-masing persentase sebesar 76.7\% dan 46.7\%. Dengan demikian dapat disimpulkan bahwa warna pada dodol asam jawa memiliki warna yang lebih berkualitas dibandingkan dodol mix.

Faktor yang mempengaruhi hasil penilaian tersebut dikarenakan dodol asam jawa memiliki warna coklat gelap alami yang dihasilkan dari daging asam jawa dan gula merah. Sebenarnya tidak ada standar warna tertentu pada dodol, dikarenakan pada umumnya dodol berwarna coklat sehingga dodol asam jawa akan terlihat memiliki kualitas yang baik.

\section{SIMPULAN}

Penelitian Kreasi Produk Camilan Dodol Asam Jawa ini dapat disimpulkan bahwa dari hasil uji organoleptik yang dilakukan oleh 30 panelis terlatih dengan melakukan uji hedonik dan mutu hedonik maka diperoleh hasil bahwa penggunaan daging asam jawa sebagai salah satu bahan baku dalam pembuatan dodol asam jawa dan dodol mix dari aspek rasa, tekstur, 
aroma, warna, dan penampilan mendapat respons beragam. Dodol mix dilihat dari aspek rasa, tekstur, aroma, dan penampilan dinyatakan lebih unggul dibandingkan dodol asam jawa. Dodol mix memiliki karakteristik yang berbeda, dimana dodol mix terdiri dari dua lapis dodol yang berbeda, serta adanya penambahan kacang tanah pada salah satu lapisan dodol, yaitu pada dodol original. Sedangkan dodol asam jawa merupakan dodol dengan karakteristik yang klasik, mirip dengan dodol pada umumnya yang memiliki satu warna, satu rasa, dalam satu produk. Pernyataan tersebut didukung dengan uji t yang dilakukan terhadap dua sampel yang tidak berkaitan, yaitu dodol asam jawa dan dodol mix. Dodol asam jawa dan dodol mix dinyatakan memiliki perbedaan signifikan rata-rata hasil penilaian panelis terhadap rasa. Pada aspek tekstur, aroma, warna, dan penampilan dodol asam jawa dan dodol mix dinyatakan tidak memiliki perbedaan signifikan rata-rata hasil penilaian panelis.

Dodol merupakan makanan tradisional yang memiliki varian rasa khas pada setiap daerah di Indonesia. Resep yang dikembangkan pada penelitian ini dapat digunakan sebagai alternatif dalam mengelola asam jawa, terutama pada daerah penghasil asam jawa yang melimpah. Resep tersebut dapat gunakan atau dikembangkan sebagai ide usaha guna meningkatkan nilai jual asam jawa dengan mengolahnya menjadi dodol.

\section{UCAPAN TERIMA KASIH}

Penulis mengucapkan terima kasih kepada LPPM UPH yang telah memberikan kesempatan melaksanakan penelitian ini

(P-084-M/FPar/XI/2019)

\section{DAFTAR PUSTAKA}

Badan Penelitian dan Pengembangan Pertanian. (2012). Aneka Olahan Buah dan Sayur. In IAARD Press. IAARD Press.

Balai Penelitian Tanaman Industri dan Penyegar. (2011). Potensi Tepung Biji Asam Jawa Sebagai Pengental Cetak Tekstil. http://balittri.litbang.pertanian.go.id/index.php/berita/berita-lain/75-potensi-tepung-bijiasam-jawa-sebagai-pengental-cetak-tekstil

Beck, L. (2018). Coconut sugar: Is it healthier than white sugar, or just hype? - The Globe and Mail. The Globe and Mail. https://www.theglobeandmail.com/life/health-andfitness/ask-a-health-expert/coconut-sugar-is-it-healthier-than-white-sugar-or-justhype/article19187927/

Ginting, H. S. P., \& Prof. Dr. Hamam Hadi, MS, S. D. (2012). Konsumsi makanan tinggi karbrohidrat, protein, lemak sebagai faktor risiko kejadian dislipidemia pada dosen Universitas Gadjah Mada yang melakukan medical check up di GMC-Health Center 
Yogyakata.

Hakim, L. (2015). Rempah \& Herba Kebun-Pekarangan Rumah Masyarakat (Issue 164).

Imanningsih, N. (2012). Profil Gelatinisasi Beberapa Formulasi Tepung-tepungan untuk Pendugaan Sifat Pemasakan. Penel Gizi Makan, 35(1), 13-22. https://doi.org/10.1017/CBO9781107415324.004

Kemp, Sarah E; Hollowood, Tracey; Hort, J. (2009). Sensory Evaluation: A Practical Handbook. A John Willey \& Sons, Ltd.

Lawless, Harry T \& Heymann, H. (2010). Sensory Evaluation of Food: Principles and Practices (Second). Springe. https://books.google.co.id/books?id=yrLfrVgU6CsC\&printsec=frontcover\&hl=id\#v=one page \&q\&f=false

Lukito, Maharani Sandiana, Giyarto, J. (2017). Sifak Fisik, Kimia dan Organoleptik Dodol Hasil Variasi. Jurnal Agroteknologi, 11(01).

Matson, T. (2018). Glutinous Rice Flour - Chinese Sticky Rice Flour - Yum Of China. Yum China. https://www.yumofchina.com/glutinous-rice/

Nasaruddin, F., Chin, N. L., \& Yusof, Y. A. (2012). Effect of processing on instrumental textural properties of traditional dodol using back extrusion. International Journal of Food Properties, 15(3), 495-506. https://doi.org/10.1080/10942912.2010.491932

Nurhayati, Lasmanawati, \& Y. (2012). Pengaruh Mata Kuliah Berbasis Gizi Pada Pemilihan Makanan Jajanan Mahasiswa Program Studi Pendidikan Tata Boga Oleh: Ai Nurhayati, Elly Lasmanawati, dan Cica Yulia. 1-6.

Puspitasari, E. H. (2014). Uji Efek Ekstrak Etanol $70 \%$ Daging Buah Asam Jawa (Tamarindus indica L) Terhadap Penurunan Kadar Glukosa Darah Tikus Jantan Galur Wistar (Rattus Norvegicus) yang Diinduksi Aloksan.

Sekaran, Uma \& Bougie, R. (2016). Research Methods For Business: A Skill Building Approach (Seventh). John Wiley \& Sons.

The Sugar Association. (2017). About Sugar; A Consumer Fact Sheet. In The Sugar Association, Inc. https://doi.org/10.1080/00221341408983659

Tipvarakarnkoon, T. (2009). Material science properties of coconut milk, cheese and emulsion. Thesis.

Waluyani, D. O. (2012). Asam Jawa, Pemberi Cita Rasa Asam Alami. Detik Food. https://food.detik.com/info-bahan/d-1928599/asam-jawa-pemberi-cita-rasa-asam-alami 
Abdimas Berdaya: Jurnal Pengabdian Masyarakat Vol. 3 No. 01 (2020)

P-ISSN: 2685-1563, E-ISSN: 2720-9768 